\title{
Designing Serious Game as Learning Media of Design Thinking Mindset
}

\author{
Ahmad Syahid Zakaria \\ Industrial Engineering \\ Universitas Indonesia \\ Depok, Indonesia \\ ahmadsyahidzakaria@gmail.com
}

\author{
Billy Muhamad Iqbal \\ Industrial Engineering Universitas \\ Indonesia \\ Depok, Indonesia \\ billy.iqbal@ie.ui.ac.id
}

\author{
Danu Hadi Syaifullah \\ Industrial Engineering Universitas \\ Indonesia \\ Depok, Indonesia \\ danuhadi@ui.ac.id
}

\begin{abstract}
In many cases, the concept of design thinking (DT) is only taught as an instance method without deep understanding of its basic concepts. The characteristic of DT itself is abstract and practical so difficult to be articulated. On the other side, serious game (SG) comes as a proven solution that can bring a positive impact on the learning process because it can provide an immersive and enjoyable experience. In general, this research will discuss how to design the most appropriate SG to embed the basic concept of DT and how its influence on DT learning process at the participant's reaction and learning level. This study discusses comprehensively the design process of SG starting from game model, game framework, design sketch, to final prototype. The output of this design is a series of educative games composed of several aspects of meaning and play to teach the basic concept/mindsets of DT.
\end{abstract}

Keywords-Design Thinking, Serious Game, Level of Reaction and Learning.

\section{INTRODUCTION}

In 2015 quoted from the cover of the Harvard Business Review, Jon Kolko argues that design thinking/DT has become the peak of the trend. In response to these issues, DT experts: Tim Brown, Roger Martin, and Kolko did various changes into the basic concepts from product design to a wider field with more complex issues. Basically, DT is about good design, and good design can give better income. According to Design Management Institute and Motiv Strategies, a company similar to Apple, Coca Cola, Walt Disney, etc. proven to produce $219 \%$ of S\&P 500 for 10 years from 2004 to 2014 as released in Fig. [1].
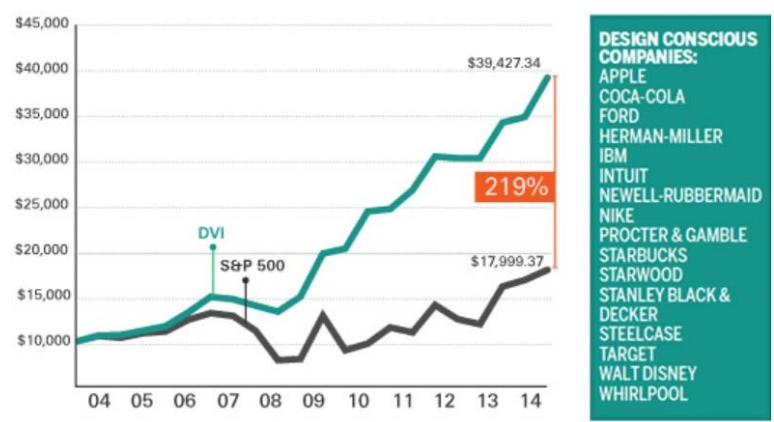

Fig. 1. Design Value Index (DVI) 2004 - 2014
The term design thinking was first popularized by Tim Brown and David Kelley as the founders of IDEO in 2008. This concept has continued to grow rapidly and has been adopted by companies from all different fields and levels. This approach is often referred to as the 'magic method' for solving a problem because in some cases it has succeeded in providing a unique solution to a variety of fairly complex problems. By definition, design thinking is a human-focused approach and collaboration to solve problems creatively, iteratively, and practically [2].

According to Samuel Tschepe based on the interpretation of Hassi \& Laakso [3] and Carlgren, Rauth, \& Elmquist [4], design thinking is more complex than just a collection of methods, but a mindset and work attitude for creative problem solving based on principle: focus on user, problem mapping, collaboration, experimentation, and visualization. More coherently, the whole aspect of the DT is composed of three levels as in Fig. 2.

One of the biggest problems with the concept of design thinking is the ambiguity of the concept [5]. This leads to various interpretations of ideas that confuse ordinary people to participate in learning and discussion. This may be an obstacle to the process of adoption and implementation in an organization. In addition, different interpretations open the possibility that the use of DT is misinterpreted as something else [6]. The quality of a design thinking training plays an important role in improving the understanding of the material presented. But unfortunately, in reality the application of learning process in some cases has not run optimally.

\begin{tabular}{|c|c|c|c|c|c|}
\hline \multirow{2}{*}{ Level 1} & \multicolumn{5}{|c|}{ Principtes } \\
\hline & Userfocus & Problem framing & Collaboration & Experimentation & Visualization \\
\hline \multirow{4}{*}{ Level 2} & \multicolumn{5}{|c|}{ Mindsets } \\
\hline & $\begin{array}{l}\text { Emphatic, curious, } \\
\text { interested in people } \\
\text { and unprejudiced }\end{array}$ & $\begin{array}{l}\text { Think holistically, } \\
\text { cross-linked, and } \\
\text { unexpected }\end{array}$ & $\begin{array}{l}\text { Think integratively } \\
\text { and be open to } \\
\text { differences }\end{array}$ & $\begin{array}{c}\text { Explorative, } \\
\text { optimistic, willing to } \\
\text { learn and analytical }\end{array}$ & $\begin{array}{l}\text { Think visually and } \\
\text { have bias towards } \\
\text { action }\end{array}$ \\
\hline & \multicolumn{5}{|c|}{ Work Atritudes } \\
\hline & $\begin{array}{l}\text { - Seek to under- } \\
\text { stand from the } \\
\text { perspective of } \\
\text { user. } \\
\text { Use qualitative } \\
\text { context-specific } \\
\text { approach }\end{array}$ & $\begin{array}{l}\text { - Challenge and } \\
\text { reframe initial } \\
\text { problem } \\
\text { - Synthesize data } \\
\text { - Consider diffe- } \\
\text { rent possibilities }\end{array}$ & $\begin{array}{l}\text { - Work in diverse } \\
\text { - Seek diverse } \\
\text { perspective } \\
\text { - Challenge } \\
\text { common } \\
\text { understanding } \\
\text { - Cross-working }\end{array}$ & $\begin{array}{l}\text { - Work iteratively } \\
\text { : Prototype quichly } \\
\text { : Test early } \\
\text { - Fail often }\end{array}$ & $\begin{array}{l}\text { - Make ideas and } \\
\text { insight visually } \\
\text { - Make rough } \\
\text { representation } \\
\text { - Provide } \\
\text { experience }\end{array}$ \\
\hline \multirow[b]{2}{*}{ Level 3} & \multicolumn{5}{|c|}{ Methods } \\
\hline & $\begin{array}{l}\text { Persona, empathy } \\
\text { mapping, user } \\
\text { joumey napping }\end{array}$ & $\begin{array}{l}\text { Point of view and } \\
\text { how might we }\end{array}$ & $\begin{array}{c}\text { Teambuilding } \\
\text { activities }\end{array}$ & \multicolumn{2}{|c|}{$\begin{array}{c}\text { Brainstorming technique, sketching creatio } \\
\text { of mockup and prototype }\end{array}$} \\
\hline
\end{tabular}

Fig. 2. Design Thinking Model 
As one of the research opportunities, nowadays especially in the field of training practice, game-based learning method or often known as serious game proven to solve various problems in the learning process. As one of the studies that have been done by Yasin, Liu, Li, Wang, \& Zowghi [7], about Security Requirements Education Game / SREG, the results showed a positive relationship between learning-based games with the effectiveness of the training. In addition Landers and Callan with the design of serious games on military field and Helser with game-based learning about identity theft, has shown that serious game may increase the effectiveness of learning, give positive experiences and increase motivation or intention to learn [7].

From that problems and opportunities, the researcher is interested to implement the concept of the serious game design to solve the problem in the learning process of design thinking especially to give more understanding about its basic concept. The implementation of serious game-based design has been done in various fields of learning from health, computer science, education, and human computer interaction [7]. Many researchers have measured the implementation of this concept in the learning process resulting in increased engagement and experience. But unfortunately on the other hand, serious game implementation in design thinking has not been done optimally so this research needs to be done in order to propose the appropriate solutions and also to know the influence of the implementation of serious game designed in the learning process of design thinking in general. As for the case, it can be compiled research questions, that is: "How is the game design that most appropriate for design thinking learning?" and "How does a serious game implementation affect design design learning in general?"

\section{LITERATURE STUDY}

After determining the problems, researcher need to conduct literature study about several aspect before designing the solution. In more detail, literature study is conducted to understand more about design thinking, serious game, and kirkpatrick evaluation model.

\section{A. Design Thinking}

Design thinking/DT can be defined as a user-centered approach to innovation. This has been introduced as a management approach that brings creativity and centering in humans as a new way of working [2]. Over time, this concept is increasingly associated with a method of solving a complex and complicated problem or often called the term wicked problems [4]. Implementation of design thinking in education and industry continues to grow along with changes in consumer behavior in determining the product they want. According to Liedtka, the use of design thinking can lead to a competitive advantage. Translating a need into a design criterion can provide the foundation for an ideational stage that needs and wants that are not articulated by users are the basis of different value proportions. Implementation of this concept continues to evolve over time. On the other hand, growing concerns about DT have emerged from both academics and practitioners that this approach has been claimed to be fuzzy and overly abstract. Several studies have been done to solve the problem of ambiguity in design thinking. As Hassi and Laksso did in 2011, DT is an integrated framework of three dimensions: mindset, thinking style, and practice [3].

\section{B. Serious Game}

Serious game is a kind of game designed specifically for main purpose other than purely as a medium of entertainment [8]. This type of game has been applied in various sectors such as health, defense, education, law, environment, and growing over time. According to Professor Michael Zyda, Director of the USC Game Pipe Los Angeles Laboratory, the definition of a serious game more specifically is "a challenge to the game's brain that involves adherence to entertainmentspecific rules to achieve goals related to institutional or professional training education,policy, or communication".

Research on the serious games has been done from the design process to the evaluation of its implementation. One study conducted about this topic is a study did by the British Educational Research Association in 2013. According to Mayer et al. [9], research on the serious game should be done through four stages including: understanding of initial goals, pre-game observation, post-game observation, and evaluation of the ultimate goal [9]. In many cases serious game has already proven as a media that can give positive impact and increase learning effectiveness. Besides that, serious game also may improve the engagement between the provider and the recipient of the knowledge in the knowledge transfer process [10].

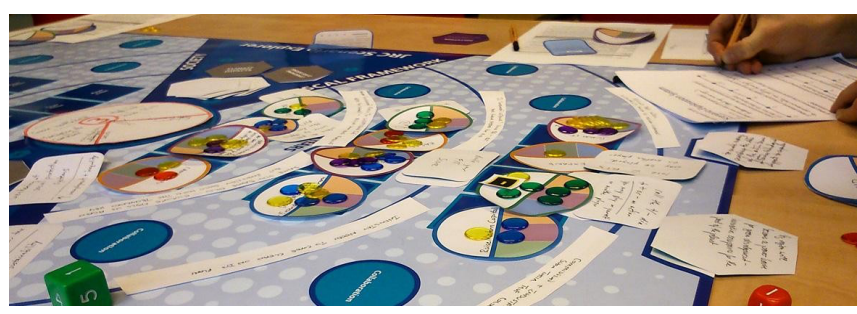

Fig. 3. Serious Game Design

\section{Kirkpatrick Evaluation Model}
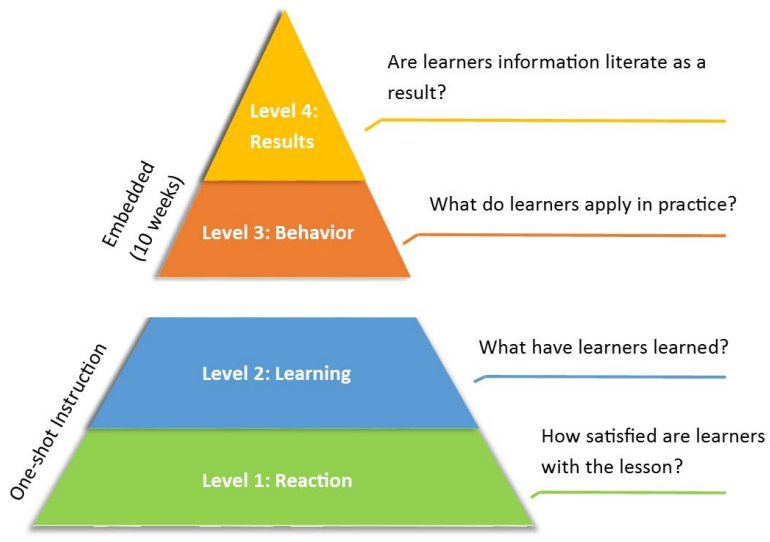

Fig. 4. Kirkpatrick Evaluation Model 
A very common method used to measure the effectiveness of a training or learning process is Kirkpatrick's four level evaluation model. This model consists of four levels including: reaction, learning, behavior, and results. The reaction rate measures what the participants think and feel about the learning process being undertaken. The level of learning evaluates the improvement of outcomes on knowledge and / or abilities and behavioral changes. The level of behavior evaluates changes in work behavior based on the program determined. Finally, the level of result evaluates the outcomes obtained due to the arrival and participation of the learning process undertaken.

Evaluation with this model can also be used to evaluate the effectiveness of the serious games as Tian, Liu, Yin, Luo, $\& \mathrm{Wu}$, used in their research about simulation-based training for aircraft carrier marshalling to measure reaction and learning rates to determine the effect of game design implementation that has been made [11].

\section{METHODOLOGY (DESIGN)}

In the process of designing the game, researchers follow the framework of Duke et al. [12], refers to his research entitled Policy Game for Strategy and Change which consists of five stages of design, which are: setting up the stage, clarifying the problem, designing the game, developing the game, and deployment [12].

\section{A. Setting up the stages}

According to Duke et al. this stage is the initial stage of designing the game that contains the determination of the underlying problem. Design thinking is currently at the top of the trend with its massive application in the world of education and bussiness. This concept is quite popular and much in demand by various levels of industry as it proves to have an effect on corporate profits big enough to $219 \%$ above S \& P 500 in 2014 [1]. This concept is also widely adopted by various startups because in some cases have succeeded in assisting the startup in finding solutions to the products / services they offer [6].

But on the other hand on this concept there are still some problems, especially on the process of understanding. According to Kimbell [13] and Lindgaard \& Wesselius [5] the concept of design thinking itself is ambiguous and difficult to understand even for those who claim to have practiced it. According to Carlgren et al. [4] and Hassi \& Laakso [3] design thinking is not just a concept that contains a set of methods, but an approach with a conceptual flow of principles, patterns thought, work attitude, and method of solving problem that is creative, iterative, and practical [2]. But in most implementation, DT is only seen as an instant method to solve a complex problem.

\section{B. Clarifying the problem}

This stage describes the focus of the problem to be solved. According to the results of the previous research that has been done, the problems that occur in the learning process DT was in the level of understanding of principles and mindset so that participants have difficulty to understand DT as a method [3][4]. This is supported by the results of qualitative and quantitative data in initial study that shows the tendency of participants have difficulty at understanding the basic concept of DT especially the transition between empathy and define phase.

If studied base on the knowledge creation of the concept of design thinking itself, according to the type of knowledge can be divided into two concepts that are tacit and explicit concept [14]. The process of transition from stage empathy to define is also the transition from explicit to tacit knowledge, or in the concept of knowledge sharing is also uderstood as internalization process.

Knowledge of explicit types is often referred to as concrete knowledge that is easily articulated because it is stored in the form of artifacts such as books and digital documents such as online. While the type of tacit knowledge which is also often referred to as abstract knowledge is a difficult knowledge to be articulated because it is stored in the human brain. Perhaps in the context of its understanding there are problems for both types of knowledge, but in some cases tacit knowledge has more potential problems for its understanding because by its very nature this kind of knowledge is context-specific knowledge so it is very difficult to be stored intact and well articulated [15]. In addition this change of phase from explicit to tacit also causes different interpretations between person.

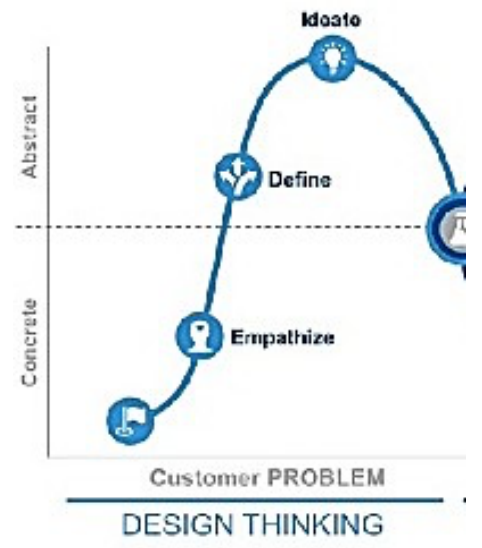

Fig. 5. Knowledge Creation in Design Thinking

According to several other literature studies that specifically discuss the transition of the process of empathy to define. The concept in a design process can generally be referred to as the fuzzy front end stage as can be seen in Fig.

5. This phase is a complex phase for a designer because here, the designer must determine the main focus of the problem raised (define) from some situation or symptoms of existing problems (empathy). 


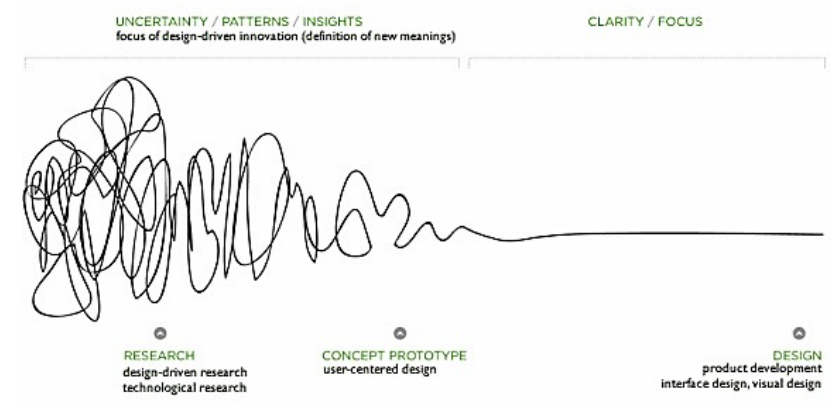

Fig. 6. Fuzzy Front End in Design

From the exposure, it can be drawn a specific design focus that will be done in order to solve the previously mentioned problem is the design of the game as the main medium of learning DT basic principles that accomodate understanding the concept from empathy to define, that are: user focus, problem framing, collaboration, experimentation, and visualization. Where these five principles ideally should be understood by a designer before using the various methods contained in the DT.

So systematically, as for the purpose of the game (meaning) that will be designed that can facilitate participants in:

1) Understand the concept of user focus practically

2) Understand the concept of problem framing practically

3) Understand the concept of collaboration practically

4) Understand the concept of experimentation practically

5) Understand the concept of visualization practically

6) Understand the concept of fuzzy front end practically

7) Understand the concept of empathy-define in general with case studies

In addition to the purpose of learning (meaning) that stated before, there are also other elements of the serious game that must be met is the play elements, where a participants will be expected to:

1) Feel the pleasure in playing (fun)

2) Feeling motivated to play (engagement)

3) Feeling carried into the game (immersive)

\section{Designing the game}

After clarifying the problem, the next step is designing the game. The order of design process start from determining LM-GM framework, than continue with designing the game models, and the last start to sketch the initial prototype. Because we are going to design serious games, we need to define learning mechanics (serious) and game mechanics (games). And here is an LM-GM framework that has been adapted to a pre-defined problem.
TABLE I. LEARNING MECHANICS

\begin{tabular}{|c|c|}
\hline $\begin{array}{l}\text { Learning } \\
\text { Mechanics }\end{array}$ & Implementation in Serious Game Design \\
\hline Fuzzy Front End & $\begin{array}{l}\text { A player will be brought to a state of determininga } \\
\text { specific, specific object of a collection of } \\
\text { abstract things. }\end{array}$ \\
\hline $\begin{array}{l}\text { DT Mindset in } \\
\text { General }\end{array}$ & $\begin{array}{l}\text { Players will feel the learning directly or indirectly } \\
\text { related to the mindset that designers should have. }\end{array}$ \\
\hline User Focus & $\begin{array}{l}\text { Players must be able to feel what other people } \\
\text { (users) feel with practice in the game. }\end{array}$ \\
\hline Problem Framing & $\begin{array}{l}\text { Players are expected to sort the problem according } \\
\text { to the context to determine the root of the problem } \\
\text { packed in the objective of each game phase. }\end{array}$ \\
\hline Collaborative & $\begin{array}{l}\text { Players experience the effects directly while } \\
\text { working alone or collaborating with other } \\
\text { participants. }\end{array}$ \\
\hline Experimentation & $\begin{array}{l}\text { Players can experiment in every turns to get } \\
\text { learning by doing learning, which should } \\
\text { experiment after iteration will give better results. }\end{array}$ \\
\hline Visualization & $\begin{array}{l}\text { Players recognize the importance of visualizing an } \\
\text { idea rather than simply expressing it in words }\end{array}$ \\
\hline Empathy-Define & $\begin{array}{l}\text { From the implicit learning of the game, participants } \\
\text { are expected to understand the processof empathy- } \\
\text { define in general. }\end{array}$ \\
\hline Case Study & $\begin{array}{l}\text { Players are expected to understand that } \\
\text { understanding in accordance with the case will be } \\
\text { able to provide more understanding because the } \\
\text { players brought into the experience directly. }\end{array}$ \\
\hline
\end{tabular}

The next step taken after defining the LM-GM framework is to create a game model that will be designed. The most suitable game model to be implemented in accordance with the meaning and play aspects that have been compiled before is a hybrid game model which is a combination of cooperative games and competition game because on the one hand a player is expected to understand the meaning of collaboration, but on the other hand the player must have an intention to win by beating other players.

TABLE II. GAME MECHANICS

\begin{tabular}{|l|c|l|}
\hline \multicolumn{1}{|c|}{$\begin{array}{c}\text { Learning Problems } \\
\text { (Initial Study) }\end{array}$} & $\begin{array}{c}\text { Game } \\
\text { Mechanics }\end{array}$ & Implementation in Design \\
\hline $\begin{array}{l}\text { There are no rules whento } \\
\text { speak, ask, or argue }\end{array}$ & Turns & $\begin{array}{l}\text { Each player has a chance to } \\
\text { speak / turn the same, with 6 } \\
\text { roles that are played in turn. }\end{array}$ \\
\hline $\begin{array}{l}\text { The presence of the type } \\
\text { of participants whoare } \\
\text { too dominant and } \\
\text { otherwise too passive in } \\
\text { the learning process }\end{array}$ & $\begin{array}{l}\text { Limited } \\
\text { resource }\end{array}$ & $\begin{array}{l}\text { Each participant has a limited } \\
\text { but balanced resource among } \\
\text { participants. }\end{array}$ \\
\hline $\begin{array}{l}\text { In reality the learning } \\
\text { process does not always } \\
\text { run ideally }\end{array}$ & Challenge & $\begin{array}{l}\text { Special condition cards (suchas } \\
\text { disability, mental } \\
\text { disability, poor, etc.) }\end{array}$ \\
\hline $\begin{array}{l}\text { The flow of } \\
\text { understanding in learning } \\
\text { design thinkingdoes not } \\
\text { seem } \\
\text { systematic and abstract }\end{array}$ & Discovery & $\begin{array}{l}\text { There is a game path to } \\
\text { complete to proceed at a later } \\
\text { stage }\end{array}$ \\
\hline
\end{tabular}




\begin{tabular}{|c|c|c|}
\hline $\begin{array}{l}\text { The intention of the } \\
\text { participants is only } \\
\text { directed to the learning } \\
\text { objectives so that it } \\
\text { seems less fun }\end{array}$ & $\begin{array}{l}\text { Fantasy } \\
\text { and } \\
\text { Narrative }\end{array}$ & $\begin{array}{l}\text { Appointed a theme for each } \\
\text { game for the purpose of } \\
\text { camouflage from the material } \\
\text { so that learning is packed with } \\
\text { narrative and fantasy } \\
\text { stories }\end{array}$ \\
\hline $\begin{array}{l}\text { The purpose of the } \\
\text { learning is contextual- } \\
\text { different in accordance } \\
\text { with the acceptance of } \\
\text { each participant }\end{array}$ & Clear Goal & $\begin{array}{l}\text { The objectives for each game } \\
\text { plot are clear so that } \\
\text { participants can follow with a } \\
\text { focus on the ultimate goal }\end{array}$ \\
\hline $\begin{array}{l}\text { In the conventional } \\
\text { learning system, there is } \\
\text { no mechanism of } \\
\text { cooperation other thanthe } \\
\text { structured }\end{array}$ & $\begin{array}{l}\text { Fellow } \\
\text { ship }\end{array}$ & $\begin{array}{l}\text { There is a part of the game that } \\
\text { demands teamwork with } \\
\text { everyone having different } \\
\text { roles. }\end{array}$ \\
\hline $\begin{array}{l}\text { The type of learning } \\
\text { varies greatly with } \\
\text { participants and } \\
\text { teachers }\end{array}$ & $\begin{array}{l}\text { Variety of } \\
\text { Styles }\end{array}$ & $\begin{array}{l}\text { Case studies are used randomly } \\
\text { by taking randomcards. }\end{array}$ \\
\hline
\end{tabular}

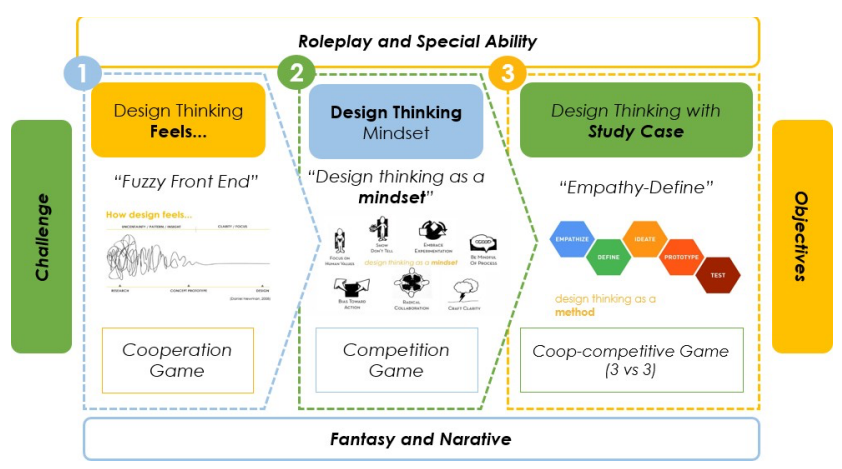

Fig. 7. Serious Game Model

In addition to the type of game, the theme raised must also be adapted to the material flow of understanding on the concept of design thinking where in general the flow of understanding that should be undertaken by the players is sequentially from the DT as a principle, as the mindset, and the latter as a method with case studies. In order for the player to still be able to feel the excitement of the game then the concept of learning is melted in a narrative story that is adapted to the context of the game plot being played. In addition to adding interaction between players will also be added features roleplay with each participant has a special ability that is distributed randomly and changed for each phase with the number of phases that are tailored to the number of participants so that each participant can feel each role, the game runs more justly. Finally, the design of the game is designed as attractive and as interactive as possible to increase the player's motivation to play and finish the game. As for the visual, the game model to be designed is as in Fig. 7.

\section{Developing the game}

In this stage, the game model developed into the game sketch like as follow:

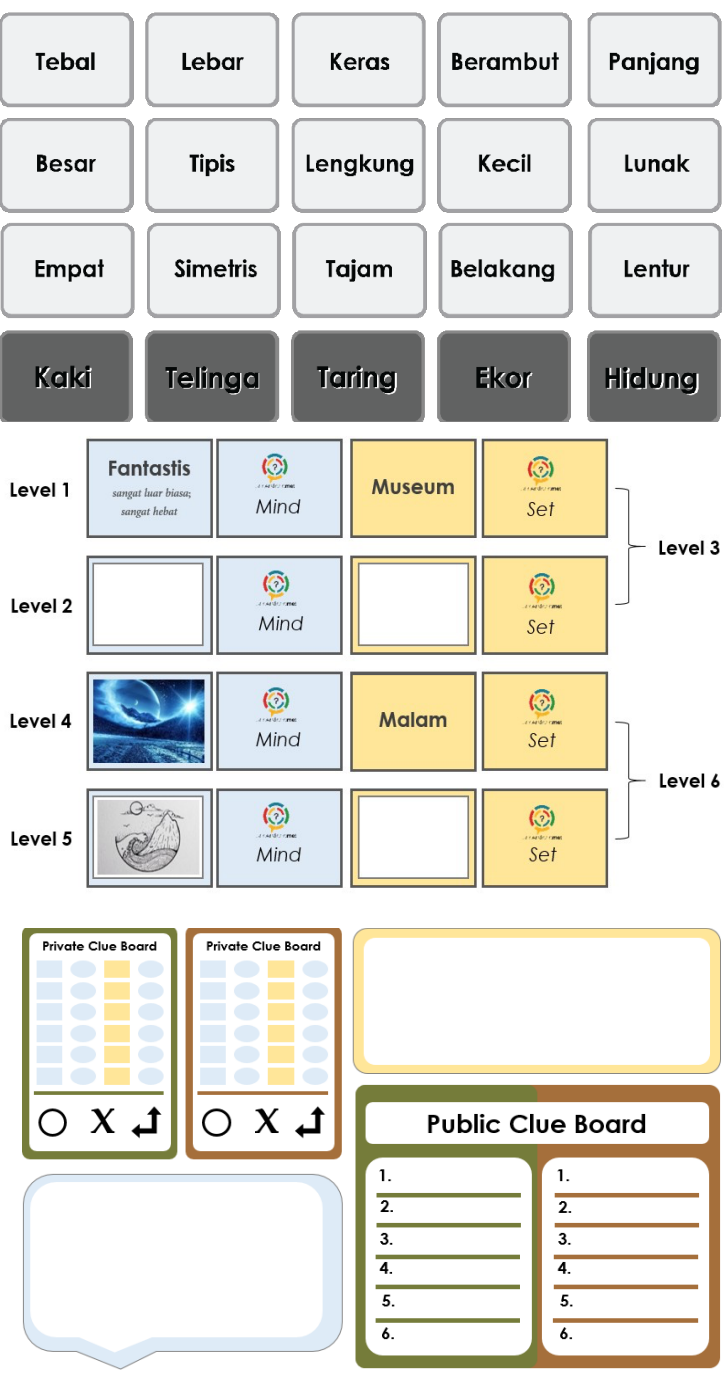

Fig. 8. Initial game sketch

After designing the game sketch, then researcher start to develop the game into the final prototype with some addition after doing cognitive walktrough method. The main additions at this stage are themes and narratives. Since this is a game that will be played, then it should be the design of the theme that best fits the context of the topic. So after performing various brainstorming processes, the researchers decided to use the alien theme in the first game, the baby in the second game, and the detective in the third game. Alien represents the process of understanding an abstract (fuzzy front end). Babies represent the process of understanding the beginners mindset. While the detective represents the case study process. Here are some pieces of the game that has been designed 

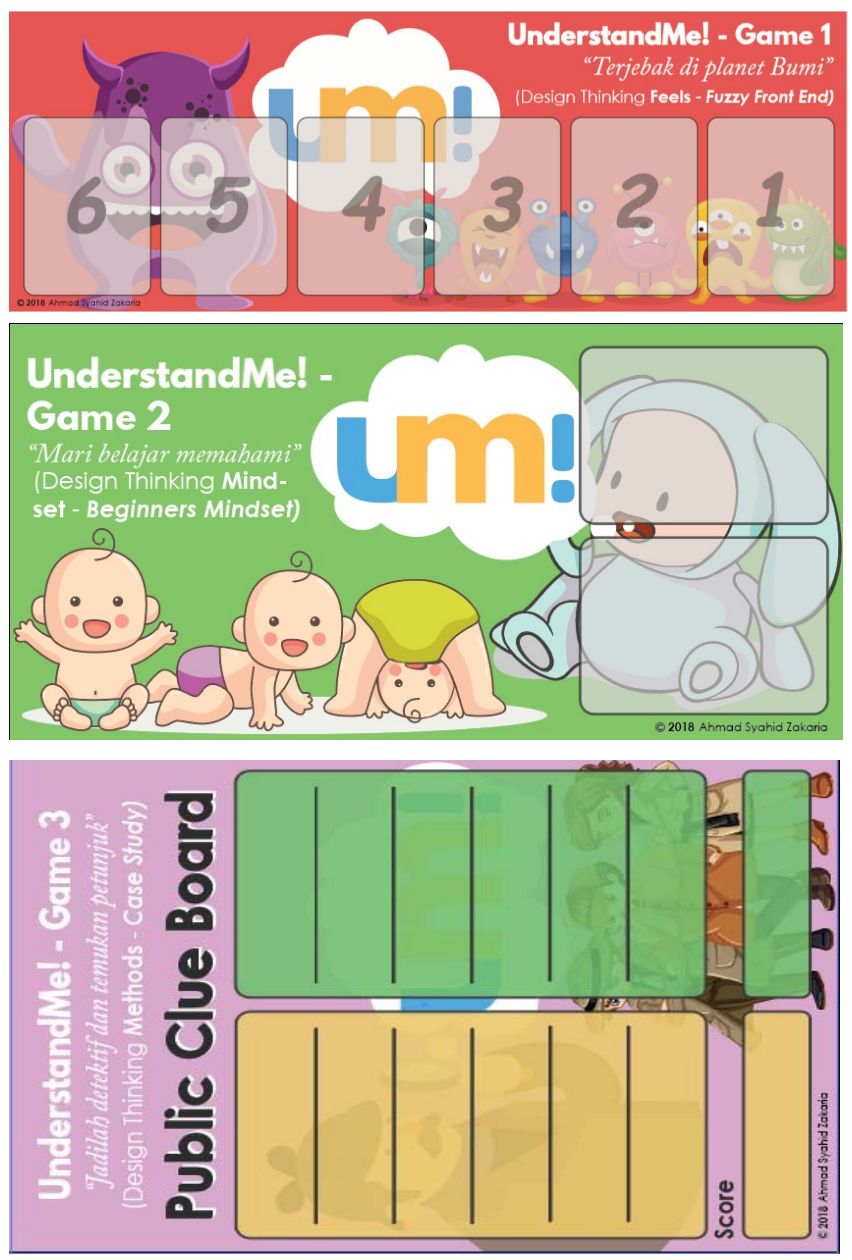

Fig. 9. Final Game Prototype

\section{E. Deployment}

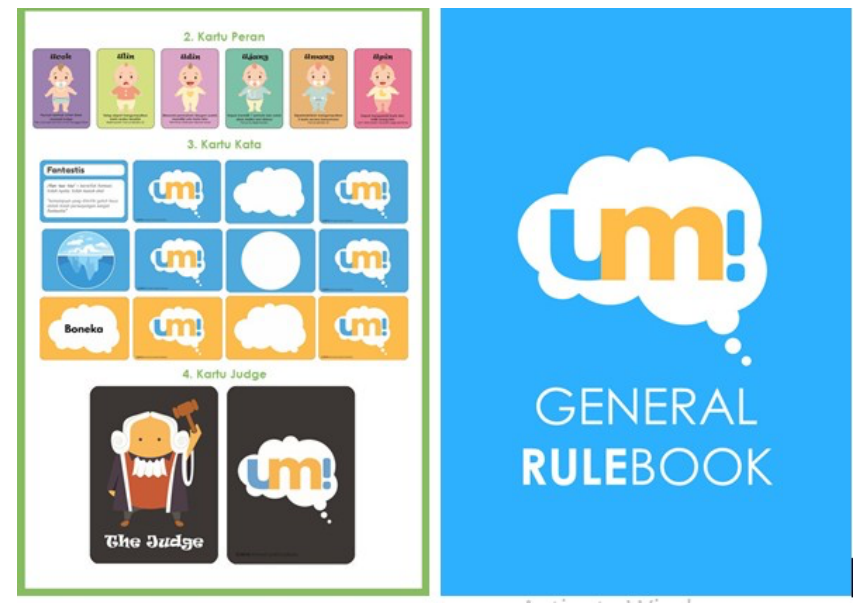

Fig. 10. General Rule Book

The last step in designing serious game is deployment. Here the researchers do the making of packaging and game rule so players can understand the flow of the game with ease. The following is one of the interface of game rule that has been designed.

\section{IV.RESUlt (EVALUATION)}

The validation process undertaken by the researcher is the measurement of the reaction rate of the participants to the designed game. Preparation of the questionnaire based on interpretation of the serious game evaluation conducted by Yasin et al. [7] using likert scale from strongly disagree until strongly agree. There are four statements measured by players' reactions after serious game play:

Q1 = this game / media is a fun method of learning

$\mathrm{Q} 2$ = this game / media has motivated me to learn moreabout design thinking (empathy - define)

$\mathrm{Q} 3$ = this game / media is easy to understand and play / use Q4 = I am motivated to play / use this game / media infuture

After collecting the data can be seen the results interpretation on the graph is as follows:

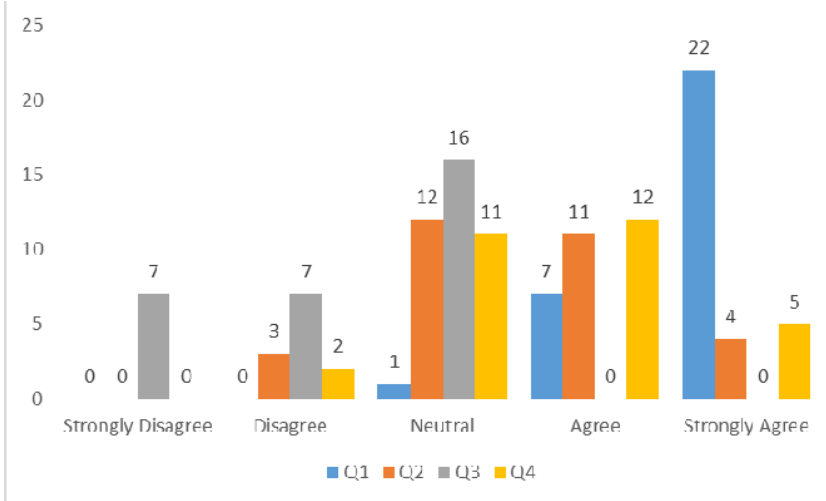

Fig. 11. Reaction Evaluation Result

It can be seen in the graph above that the respondent's tendency to react to the first statement (This game / media is a fun method of learning) is relatively strongly agree with most answers are in point 5 (Strongly Agree). For the second statement (This game / media has motivated me to learn more about design thinking (empathy - define) respondents relative agree with the tendency of answers on points 3 and 4. For the third statement about this game / media is easy to understand and play / use respondents are relatively more neutral. And for the last statement I am motivated to play / use this game / media in future, relative respondents to agree. From these results show that the media designed to have the value of excellence as a fun medium to do and need to be improved on the ease of understanding by the players.

Beside level of reaction, this research also measure the improvement of understanding of participants with the result in Table III. It can be seen in the table that the biggest improvement lies in the aspect of design thinking mindset in general, fuzzy front end, and beginners mindset. So it can be 
drawn a result that serious game game designed can teach aspects of mindset compared with other material. This is in line with the initial goal of research focusing on the cultivation of mindset design thinking. And from the research that has been done proven that the media can teach the concept even if done implicitly.

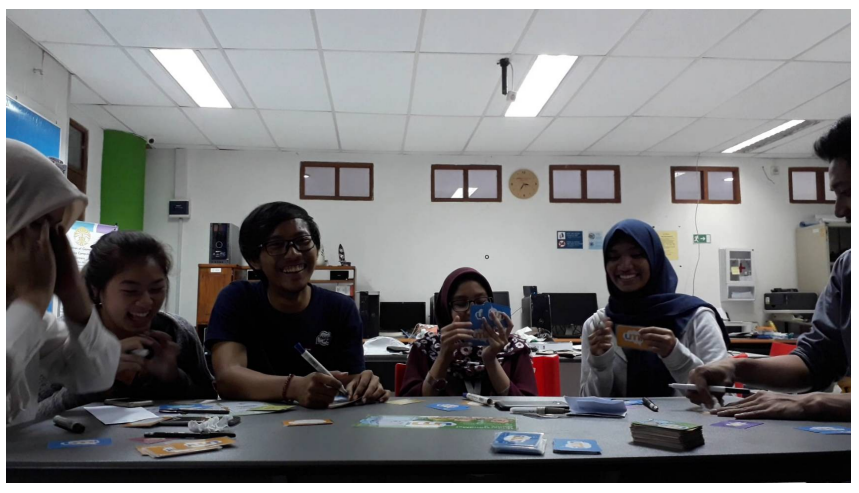

Fig. 12. Game Trials

TABLE III. LEARNING EVALUATION RESULT

\begin{tabular}{|c|c|c|c|c|c|}
\hline \multirow[b]{2}{*}{$\mathbf{L}$} & \multicolumn{2}{|c|}{ Before } & \multicolumn{2}{|c|}{ After } & \multirow{2}{*}{$\begin{array}{c}\text { Gap } \\
\text { Mean } \\
\text { Value }\end{array}$} \\
\hline & $\begin{array}{l}\text { Mean } \\
\text { Value }\end{array}$ & SD & $\begin{array}{l}\text { Mean } \\
\text { Value }\end{array}$ & SD & \\
\hline L1 & 2,031657 & 0,847 & 3,398297 & 0,504 & 1,366641 \\
\hline L2 & 1,096825 & 0,346 & 3,226511 & 0,521 & 2,129686 \\
\hline L3 & 2,156695 & 0,691 & 3,522133 & 0,724 & 1,365438 \\
\hline L4 & 2,970027 & 0,615 & 3,49748 & 0,507 & 0,527453 \\
\hline L5 & 2,707841 & 0,568 & 3,483776 & 0,571 & 0,775935 \\
\hline L6 & 2,948129 & 0,320 & 3,464102 & 0,509 & 0,515973 \\
\hline L7 & 2,215788 & 0,596 & 3,158299 & 0,679 & 0,942512 \\
\hline L8 & 1,096825 & 0,346 & 3,669259 & 0,466 & 2,572434 \\
\hline L9 & 1,203025 & 0,450 & 3,270415 & 0,466 & 2,06739 \\
\hline L10 & 3,194276 & 0,794 & 3,669259 & 0,466 & 0,474984 \\
\hline
\end{tabular}

\begin{tabular}{|c|c|c|}
\hline L1 & $=$ & Empathy-Define In General \\
\hline $\mathbf{L 2}$ & $=$ & Design Thinking Mindset In General \\
\hline $\mathbf{L 3}$ & $=$ & User Focus \\
\hline $\mathbf{L 4}$ & $=$ & Problem Framing \\
\hline $\mathbf{L 5}$ & $=$ & Collaboration \\
\hline L6 & $=$ & Experimentation \\
\hline L7 & $=$ & Visualization \\
\hline L8 & $=$ & Fuzzy Front End (Design Thinking Feels) \\
\hline & $=$ & Beginners Mindset \\
\hline L10 & & Case Study \\
\hline
\end{tabular}

\section{CONCLUSION}

Based on the result of prototype and evaluation of serious game which have been designed in this research can be drawn a conclusion based on research question proposed at introduction part is as follows:

1) How is game based learning / serious game design that most appropriate for design thinking mindset learning?
The most serious game design for design thinking study is design concept with focus on deep planting of basic principles, mindset, and design thinking model especially in phase empathy-define. Games are generally divided into three stages: the initial briefing of the game, the process of training, and the final briefing of the game. The mainstream of the game is divided into three sub-games with different types and objectives each game. More specific games teach the five basic principles of DT implicitly about: user focus, problem framing, collaboration, experimentation, and visualization. The first game raises the fuzzy front end theme with the analogy of a bunch of aliens who are being lost and solving challenges on Earth. The second game brings up the theme of the beginners mindset with a narrative set of infants practicing speaking with six levels ranging from simple understanding to words to complex understandings through images. The third game takes the theme of case study with a narrative of competition between detectives that teaches participants to learn in the analysis of given cases. This game model was developed based on the DT concept model adopted from [4] and [3] which is an integration of a principle, mindset, work attitude, to DT practice methods. This concept is packed based on combining pedagogical elements and games with challenging, objective, narrative, and role features. Mapping is done based on the meaning and play aspects which then developed into game needs specifications and game models. In the design iteration done as much as three stages of the sketch of the model and then developed into a minimum viable product and finally developed into a prototype that can be played.

2) How is the influence of implementation of game based learning / serious game on learning design thinking?

According to the results of the verification by the researchers and the validation with the evaluation of the kirkpatrick evaluation model described in the previous chapter, it can be concluded that at the reaction level, the serious game designed gets a relatively good reaction with the majority of players responding strongly in particular to the fun method of learning. While for the level of learning, proven SG that has been designed to increase the knowledge of players on the entire sub-field is determined. Particularly in the fuzzy front end field, prior and post-training knowledge gaps receive the highest scores.

\section{ACKNOWLEDGMENT}

This research was supported by Universitas Indonesia through grant of PITTA (Publikasi Internasional Terindeks untuk Tugas Akhir). We thank our colleagues from Ergonomics Center Laboratory who provided insight and expertise that greatly assisted the research from the beginning.

\section{REFERENCES}

[1] J. Rae, "Good Design Drives Shareholder Value," 2015.

[2] T. Brown, "Tim Brown-Change by Design_ How Design Thinking Transforms Organizations and Inspires Innovation - HarperBusiness (2009)." 2009.

[3] L. Hassi and M. Laakso, Conceptions of Design Thinking in the 
Management Discourse.

[4] L. Carlgren, I. Rauth, and M. Elmquist, "Framing Design Thinking: The Concept in Idea and Enactment," Creat. Innov. Manag., vol. 25, no. 1, pp. 38-57, 2016.

[5] K. Lindgaard and H. Wesselius, "Once More, with Feeling: Design Thinking and Embodied Cognition," She Ji J. Des. Econ. Innov., vol. 3, no. 2, pp. 83-92, 2017.

[6] Bao Marianna Nguyen, "DESIGN THINKING in Startups," 2006.

[7] A. Yasin, L. Liu, T. Li, J. Wang, and D. Zowghi, "Design and preliminary evaluation of a cyber Security Requirements Education Game (SREG)," Inf. Softw. Technol., vol. 95, no. April 2017, pp. 179200, 2018.

[8] D. Djaouti, J. Alvarez, and J.-P. Jessel, "Classifying serious games: The G/P/S model," Handb. Res. Improv. Learn. Motiv. through Educ. games Multidiscip. approaches, no. 2005, pp. 118-136, 2011.

[9] I. Mayer et al., "The research and evaluation of serious games: Toward a comprehensive methodology," Br. J. Educ. Technol., vol. 45, no. 3, pp. 502-527, 2014.

[10] P. Lombriser, F. Dalpiaz, G. Lucassen, and S. Brinkkemper,
"Gamified Requirements Engineering: Model and Experimentation BT - Requirements Engineering: Foundation for Software Quality," 2016, pp. 171-187.

[11] Y. Tian, H. Liu, J. Yin, M. Luo, and G. Wu, "Evaluation of simulation-based training for aircraft carrier marshalling with learning cubic and Kirkpatrick's models," Chinese J. Aeronaut., vol. 28, no. 1, pp. 152-163, 2015.

[12] J. L. A. Geurts, R. D. Duke, and P. A. M. Vermeulen, "Policy Gaming for Strategy and Change," Long Range Plann., vol. 40, no. 6, pp. 535$558,2007$.

[13] L. Kimbell, "Rethinking Design Thinking: Part I," Des. Cult., vol. 3, no. 3, pp. 285-306, Nov. 2011

[14] B. I. Pasaribu, A. Afrianti, G. G. Gumilar, H. P. Rizanti, and S. Rohajawati, "Knowledge Transfer: A Conceptual Model and Facilitating Feature in Start-up Business," Procedia Comput. Sci., vol. 116, pp. 259-266, 2017.

[15] J. L. Ermine, "Introduction to Knowledge Management," Trends Enterp. Knowl. Manag., pp. 21-43, 2010 